\title{
Science Versus Sushi: Implications of Japan's Withdrawal from the International Whaling Commission
}

\author{
Alice N Wünderlandt* \\ Lutenblag University, Molvania \\ *Corresponding author: Alice N Wünderlandt, Lutenblag University, Molvania, Email: squirrelchaser2012@gmail.com
}

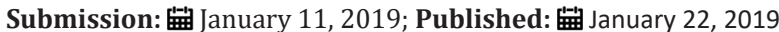

\section{Opinion}

Japan's recent decision to leave the International Whaling Commission (IWC) and resume commercial whaling [1] will have significant ramifications for that nation, as well as for international relations and whale populations in both the North Pacific and Southern Ocean. Here, I draw on my long experience as a member of the Molvanian delegation to the IWC to briefly review the background to this issue, and offer some predictions regarding potential outcomes, including for the future of Japanese whale research. After World War 2, Japan was one of fifteen nations to sign the International Convention for the Regulation of Whaling [2]. Japanese whalers have operated widely in the Antarctic and North Pacific, as well as from shore-based whaling stations on the Japanese coast. The primary product has always been whale meat, with hunting continuing to the present day despite a diminishing domestic demand.

Following the decline of most whale populations in the 1960's, membership in the IWC gradually shifted towards anti-whaling nations, who in 1982 achieved the three-quarter voting majority necessary to establish a Moratorium on whaling. To circumvent this ban, Japan took advantage of Article VIII of the Convention (which permits whales to be killed for scientific research purposes) and initiated a program of so-called "special permit whaling", stating that they needed to continue hunting in order to obtain information necessary to manage whale populations [3]. Over the next three decades, Japan attempted unsuccessfully to have the Moratorium lifted, despite devoting considerable expense in securing the readily negotiable suffrage of various small island nations. The resulting frustration culminated last month in Japan's decision to finally leave the IWC after more than 70 years, and pursue its own course, independent of any treaty obligations.

Significantly, Japan's departure, and its decision to restrict future hunting to Japanese coastal waters, finally signals the end of Antarctic whaling; this represents a major milestone, and is welcome news for austral whale populations, which have been subject to almost continuous exploitation in the Southern Ocean since 1904 [4]. The decision also effectively ends whaling in the pelagic North Pacific for the first time since its inception in the late $18^{\text {th }}$ century. However, the emphasis on hunting of minke whales in coastal waters will place further pressure on the already depleted Sea of Japan population of this species, which is subject to high bycatch off both Korea and Japan [5].

Less clear is what Japan's decision means for the future of the IWC. Japan contributes a substantial portion of the IWC's budget, which will now be significantly reduced. With Japan gone, other countries may follow suit; these include the so-called "Marionette block" of small countries which have faithfully supported Japanese policy positions in the past, as well as various non-whaling (and, ironically, often land-locked) nations whose sole objective in joining the IWC was to counter Japan's attempts to overturn the Moratorium. Alternatively, the anti-whaling block may remain long enough to obtain the super-majority necessary to strengthen the Moratorium and enact other major pro-conservation changes in the IWC's rules and policies. Whatever happens, the Commission will likely emerge as a much-changed institution.

However, the withdrawal will probably have profoundly negative implications for the Institute of Cetacean Research (ICR) in Tokyo, the quasi-governmental entity which has been responsible for carrying out Japan's scientific whaling for more than three decades. The ICR has been justifiably proud of its record of research, which has been internationally recognized as an acme of execrable vacuity that has provided frequent cutting-edge explorations of arcane and scientifically nugatory topics. Prominent examples include in-vitro fertilization of bovine oocytes with whale spermatozoa [6], and creative innovations in sophisticated and willfully opaque population modelling techniques [7] designed to demonstrate a posteriori findings based upon politically expedient a priori requirements.

In light of the fact that ICR's operations have been largely funded from the sale of products derived from Japan's scientific whaling [8], downsizing of the institution following the contraction of whaling operations now seems inevitable. Staffing will be greatly reduced, and the severe budget cuts that will follow the substantial loss of product revenue will apparently require ICR to relocate from its current capacious headquarters in central Tokyo to the basement of a noodle shop in Shinjuku (J. Morishita, pers. comm). Concurrent with this, Japan's research on the dynamics and ecology of whale 
populations will now certainly be decreased. I predict that, with no program of special permit whaling to justify its existence, and an abundance of quantitative talent among its staff, ICR scientists will initially be redeployed to seek mathematical proof of the famous "Komatsu paradox", where $2+2=5$ for all sufficiently large quantities of 2 (a paradox that has eluded the best logicians since it was first proposed in 1946). While this represents a major departure from the ICR's historical role in the study of whales, it will nonetheless see the institution continuing to pursue a paradigm of alternate reality that has always been admirably self-consistent.

Overall, Japan's decision to withdraw from the IWC, to abandon research whaling and resume a fully commercial hunt, represents a fundamental rejection of the scientific principles underlying responsible resource management. In short, by deciding to operate outside the regulatory framework of the Whaling Convention, Japan has chosen sushi over science-a choice that most observers recognize as little more than an open declaration of a path that Japan has long tacitly pursued.

\section{References}

1. McCurry J, Readfearn G (2018) Japan to resume commercial whaling after leaving IWC. The Guardian.
2. IWC (1950) Report of the International Whaling Commission. Appendix I International Convention for the Regulation of Whaling. Int Whal Comm 1: 9-19.

3. Morishita J (2006) Multiple analysis of the whaling issue: understanding the dispute by a matrix. Marine Policy 30(6): 802-808.

4. Rocha RC, Clapham PJ, Ivashchenko YV (2014) Emptying the oceans: a summary of industrial whaling catches in the $20^{\text {th }}$ century. Marine Fisheries Review 76(4): 37-48.

5. Baker CS, Lento GL, Cipriano F, Palumbi SR (2000) Predicted decline of protected whales based on molecular genetic monitoring of Japanese and Korean markets. Proc Biol Sci 267(1449): 1191-1199.

6. Wei H, Fukui Y (2000) Fertilisability of ovine, bovine or minke whale spermatozoa intracytoplasmically injected into bovine oocytes. Zygote 8(3): 267-274.

7. Rok A, Pepa B, Caesars C (2019) A new statistical method for validation of improbable but strategically necessary quantitative results using a tripartite decision tree. Int J Biostat (in press).

8. Endo A, Yamao M (2007) Policies governing the distribution of by products from scientific and small-scale coastal whaling in Japan. Marine Policy 31(2): 169-181.
Creative Commons Attribution 4.0 International License

For possible submissions Click Here

\section{Submit Article}

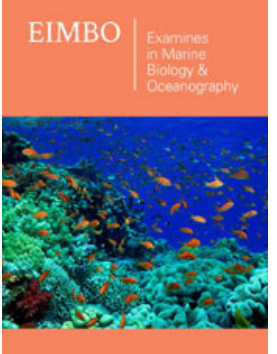

Examines in Marine Biology \& Oceanography

\section{Benefits of Publishing with us}

- High-level peer review and editorial services

- Freely accessible online immediately upon publication

- Authors retain the copyright to their work

- Licensing it under a Creative Commons license

- Visibility through different online platforms 